\title{
Coliform concentration reduction and related performance evaluation of a down-flow anaerobic fixed bed reactor treating low-strength saline wastewater
}

Nobel Rovirosa, Enrique Sánchez, Mario Cruz, Maria C. Veiga, Rafael Borja

Bioresource Technologye, Volume 94, Issue 2, 2004, Pages 119-127

DOI: 10.1016/j.biortech.2003.12.010

\section{Abstract}

Low-strength saline wastewater may be generated by tourist facilities, industries and communities located in coastal areas. Sea salts, mostly chlorides, when present in wastewaters at high concentrations, can cause inhibition on biological treatment processes. In this study, a laboratory down-flow anaerobic fixed bed reactor (DFAFBR) was used for treating saline wastewater. This wastewater was simulated by dilution of piggery manure in a synthetic saline water to obtain a final total COD concentration in the range of $1100-2900 \mathrm{mg} / \mathrm{l}$ and a salt concentration of $15 \mathrm{~g} / \mathrm{l}$. The DFAFBR was operated at hydraulic retention times (HRT) of 96, 48, 24 and $12 \mathrm{~h}$.

The results showed that at sea salts concentrations in the range from 5 to $15 \mathrm{~g} / \mathrm{l}$, total coliform concentration reduction efficiencies higher than $97 \%$ were achieved. A decrease in the total and faecal coliform concentration reduction efficiencies from 99.5\% to $90.5 \%$ and $92.5 \%$, respectively, was observed when the HRT decreased from 96 to $12 \mathrm{~h}$.

Enumeration of coliform bacteria isolated from the biofilm in different zones of the reactor showed that more than $94 \%$ of the total amount was removed in the upper zone. A HRT of $24 \mathrm{~h}$ was required to obtain total COD, organic-N, total-P and faecal coliform concentration reduction efficiencies higher than $72 \%, 51 \%$, 39\% and $98 \%$, respectively. A concentration of $8.4 \mathrm{~g} / \mathrm{l}$ for chlorides, $1.25 \mathrm{~g} / \mathrm{l}$ for sulphates and $4.6 \mathrm{~g} / \mathrm{l}$ for sodium did not affect the process performance.

\section{Keywords}

Down-flow anaerobic fixed bed reactor; Coliform concentration reduction; Lowstrength saline wastewater; Sea salts. 


\section{Introduction}

Sewage contains high concentrations of coliforms, Shigella, other pathogenic bacteria, viruses and parasites (Ogbondeminu and Okoye, 1992). Some of these are responsible for diseases like shigellosis, dysentery, typhoid fever and cholera (WHO, 1996).

Anaerobic digestion processes provide for the development of anaerobic bacteria, limiting the survival of pathogenic organisms (Duarte et al., 1992). This competitive exclusion is even higher in fixed-film anaerobic reactors than in suspended biomass reactors because of the increased adsorption, electrostatic forces and other physicalchemical phenomena, thereby improving the suspended solids retention (Henze and Harremoes, 1983; Morris and Yehuda, 1990; Cullimore and Viraraghavan, 1994; Sánchez et al., 1995 and Sánchez et al., 1997; Reyes et al., 1999). Low-strength saline wastewaters may originate from seafood processing industry, water cooling systems and other industrial activities in coastal areas. Effluents with COD values of between 200 and $2000 \mathrm{mg} / \mathrm{l}$ are produced in this industry. Many tourist and urban coastal facilities use sea water or brackish water for toilet flushing and washing because of the local scarcity of tap water (Smith et al., 1996; Parr et al., 1997). Sodium chloride ( $\mathrm{NaCl}$ ) is present in combined sewerage systems due to the treatment of snow during winter and marine intrusion. Concentration of salts in sewage water was found to be in the range of 2-8 g/l in coastal areas (Chabalina, 1996). High concentrations of salts cause cell plasmolysis and death of microorganisms usually present in sewage due to the increase of osmotic pressure (Kargi and Dincer, 1997). Some microorganisms present in faeces are more sensitive than others. Staphylococcus aureus grows in solutions containing up to $65 \mathrm{~g} / \mathrm{l}$ of $\mathrm{NaCl}$, while Escherichia coli is inhibited at a concentration of $30 \mathrm{~g} / \mathrm{l}$ ( Brock, 1970). Studies carried out in activated sludge, rotating biological contactors and anaerobic digestion processes have demonstrated that $\mathrm{Na}^{+}$and $\mathrm{Cl}^{-}$ions are inhibitors of biological processes ( $\mathrm{Li}$ and Gouwei, 1993; Omil et al., 1995; Kargi and Uygur, 1997a and Kargi and Uygur, 1997b). The effect of $\mathrm{NaCl}$ and ammonium chloride $\left(\mathrm{NH}_{4} \mathrm{Cl}\right)$ on methanogenic associations activity has been evaluated in semi-continuous flow-through reactors ( De Baere et al., 1984). In these studies, two reactors received shocks of $\mathrm{NaCl}$ and $\mathrm{NH}_{4} \mathrm{Cl}$ concentrations while other two were progressively adapted to increasing salt levels during a period of 45 days. Total inhibition occurred at shock treatments of $30 \mathrm{~g} / \mathrm{l}$ for both salts, while the other two tolerated concentrations of up to 45 and $65 \mathrm{~g} / \mathrm{l}$ for $\mathrm{NH}_{4} \mathrm{Cl}$ and $\mathrm{NaCl}$, respectively during progressive adaptation. Lens et al. (1998) reported that a considerable COD removal could be achieved via sulphate reduction when the $\mathrm{COD} / \mathrm{SO}_{4}{ }^{2-}$ ratio was near to 0.67 . On the other hand Veiga et al. (1994) reported that at ratio of $\mathrm{COD} / \mathrm{SO}_{4}{ }^{2-}$ close to 8:1, toxicity resulted when sulphate was reduced to sulphide during the anaerobic process. The authors also explained that process failure occurred when the $\mathrm{H}_{2} \mathrm{~S}$ concentration reached $5 \%$ in the gas phase at a $\mathrm{pH}$ lower than 7 in the liquid phase. At a $\mathrm{pH}$ higher than 7, the system was more stable due to the reduction of sulphide concentration in the alkaline media. Lens et al. (1998) also reported that the un-dissociated $\mathrm{H}_{2} \mathrm{~S}$ was toxic to anaerobic digestion at concentrations in the range of $90-250 \mathrm{mg} / \mathrm{l}$ for $\mathrm{pH}$ values in the ranges from 6.4 to 8.0 , respectively. On the other hand, it has been found that higher sulphide concentrations can be tolerated in anaerobic filters operating at neutral pH levels ( Parkin et al., 1991). Kugelman and McCarty (1965) studied the inhibitory effect of sodium alone on methanogenic activity and compared this to that resulting from other metallic cations. In this study sodium proved to be the strongest inhibitor on a molar basis. Sodium caused moderate inhibition at 3.5-5.5 g/l and strong inhibition at $8 \mathrm{~g} / \mathrm{l}$. However, McCarty and 
McKinney (1961) and Feijoo (1991) found that toxicity of $\mathrm{Na}^{+}$could be reduced by the presence of other cations such as calcium and magnesium. Although there are previous reports in the literature about saline wastewaters treatment by biological processes, none of them was focused on the capacity of such processes to remove coliform bacteria.

The aim of this work was to evaluate the performance of a down-flow anaerobic fixed bed reactor (DFAFBR) for coliforms removal when treating low-strength saline wastewater at different hydraulic retention times (HRTs). In order to complete this study, total COD, organic nitrogen and total phosphorus removals at steady-state conditions were also determined. Additionally, coliform bacteria were isolated and enumerated at three levels within the reactor, and the concentration of sulphate-reducing bacteria in the raw and digested sludge was also determined.

\section{Methods}

\subsection{Reactor}

The down-flow anaerobic fixed bed reactor (DFAFBR) consisted of a polyvinyl chloride (PVC) cylinder with $1.40 \mathrm{~m}$ of total height and a $4.8 \mathrm{~cm}$ internal diameter (ID). The total and working volumes of the reactor were 2 and 1.4 l, respectively. In the upper part of the reactor, a two-hole stopper was placed; one hole for influent feeding and the other to provide a biogas outlet. The biogas produced was stored in an air tight $350 \mathrm{ml}$ plastic bag and measured with a gas flow meter with a water seal once the bag nominal volume was completed. The liquid level in the filter was controlled by an overflow at a height of $1.30 \mathrm{~m}$. A port for digested sludge withdrawal was placed in the bottom of the reactor.

The anaerobic reactor was packed with ceramic rasching rings having a height of 15.5 $\mathrm{mm}$, an external diameter of $6.6 \mathrm{~mm}$ and an internal diameter of $3 \mathrm{~mm}$, approximately. The porosity of the packing was $70 \%$, and the total and specific surface areas were 11.50 and $75 \mathrm{~m}^{2} / \mathrm{m}^{3}$, respectively. The rings were randomly placed to fill the filter with a height of $1.25 \mathrm{~m}$.

\subsection{Reactor operation}

The DFAFBR was operated continuously during a period of 335 days to acclimate anaerobic bacteria to a saline environment. Wastewaters with seawater salts concentrations of $5 \mathrm{~g} / \mathrm{l}$ were added at the beginning of the experiments and $10 \mathrm{~g} / \mathrm{l}$ were added 210 days later. Thus, the reactor operated 210 and 125 days with a substrate containing 5 and $10 \mathrm{~g} / \mathrm{l}$ of sea salts, respectively. During this acclimation period, the HRT varied in the range from 96 to $12 \mathrm{~h}$. The reactor was initially inoculated with 250 $\mathrm{ml}$ of anaerobic digested sludge containing $8 \%$ total solids and $65 \%$ of volatile solids concentration. This was obtained from a pilot-scale cattle manure digester and operated without salts addition during a period of 65 days. After this period, the reactor operated continuously for 126 days and was fed with a wastewater containing a salt concentration of $15 \mathrm{~g} / \mathrm{l}$. The effect of the hydraulic retention time (HRT) was evaluated at 12, 24, 48 and 96 h during 48, 23, 28 and 27 days, respectively. The experiments were carried out at a mean room temperature of $26.7^{\circ} \mathrm{C}$. Samples of influent and effluent were collected one and three times per week respectively and analysed to determine: total COD, 
organic-N, total-P, sulphates, $\mathrm{pH}$ and total and faecal coliforms. All of these parameters were analysed according to Standard Methods for the Examination of Water and Wastewater (APHA, 1989). Specifically, organic-N, total-P and sulphates were analysed using the semi-micro Kjeldahl, stannous chloride reagent and cloudiness methods, respectively. Sulphate-reducing bacteria (SRB) were determined using the 9240C standard method (APHA, 1989). Methane concentration in the biogas was measured twice a week by means of an infrared detector (Siemens). Total and faecal coliform were also determined in the biofilm attached to the support medium and sulphate-reducing bacteria were determined in the digested sludge collected at the bottom of the reactor. Coliform concentrations in the biofilm were determined at the end of the experiment, taking samples at different heights of the reactor, upper, medium and lower. The count of coliforms and sulphate-reducing bacteria was made by the technique of the most probable number (MPN) according to APHA (1989).

The experimental data obtained were statistically evaluated by an analysis of simple variance (ANOVA), applying the test of Fisher (software package Sigmaplot 5.0) for minimum significant differences and $95 \%$ of confidence.

\subsection{Wastewater characteristics}

The saline wastewater used was prepared by diluting raw piggery manure with simulated saline water in a 1:10 volume:volume $(\mathrm{v} / \mathrm{v})$ ratio. Saline water was prepared by mixing drinking (tap) water with sodium chloride $(\mathrm{NaCl})$, potassium chloride (KCl), sodium bromide $(\mathrm{NaBr})$, magnesium chloride $\left(\mathrm{MgCl}_{2}\right)$, magnesium sulphate $\left(\mathrm{MgSO}_{4}\right)$ and calcium sulphate $\left(\mathrm{CaSO}_{4}\right)$ at concentrations equivalent to those present in seawater. The concentration of these salts, total sulphates and total chlorides of the synthetic saline water and seawater is given in Table 1.

Table 1.

Concentration $(\mathrm{g} / \mathrm{l})$ of salts, sulphates and chlorides of seawater and synthetic saline wastewater used in this study

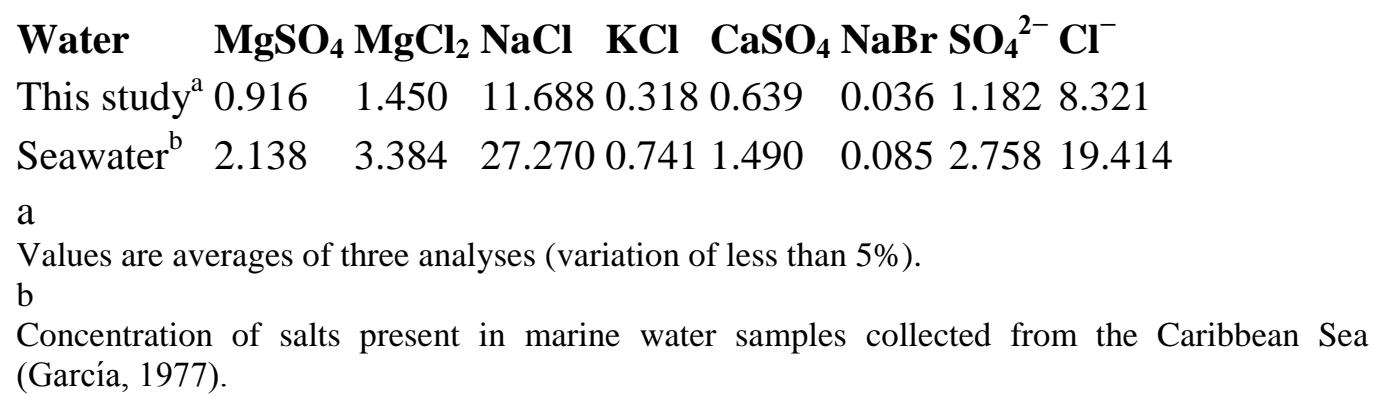

After dilution of pig manure with drinking water, these values approached those present in domestic wastewater, according to the values reported by Tchobanoglous and Burton (1991) (20-50 and 30-100 mg/l, for sulphates and chlorides, respectively). However, these values may be higher than $500 \mathrm{mg} / \mathrm{l}$ depending on the source of water supply (Lens et al., 1998). The initial concentration of these salts in drinking water was not considered because of their low values, lower than $60 \mathrm{mg} / \mathrm{l}$, in all cases (WHO, 1996). 
Raw manure with a total COD of 17.0-48.6 g/l was mixed (v/v) with the saline water in order to obtain a low-strength saline wastewater with a total COD concentration lower than $3000 \mathrm{mg} / \mathrm{l}$. The characteristics of the synthetic low-strength saline wastewater used in this work are shown in Table 2.

Table 2.

Characteristics and features of the synthetic low-strength saline wastewater used in this study

\begin{tabular}{|l|l|l|l|l|l||}
\hline Parameter & Range & Average & S.D. $^{\text {a }}$ & C.V. $^{\text {b }}$ & No. $^{\text {c }}$ \\
\hline Total COD (mg/l) & $1131-2877$ & 1919 & \pm 546 & 28 & 21 \\
\hline \hline Organic-N (mg/l) & $2.4-9.8$ & 5.2 & \pm 2.4 & 46 & 13 \\
\hline Total-P (mg/l) & $8.2-19.4$ & 13.5 & \pm 3.2 & 24 & 17 \\
\hline \hline $\mathrm{pH}$ & $7.1-7.5$ & 7.3 & \pm 0.3 & 4 & 17 \\
\hline \hline $\mathrm{TC}^{\mathrm{d}}(\mathrm{MPN} / 100 \mathrm{ml})$ & $2.1 \times 10^{4}-1.1 \times 10^{8}$ & $1.98 \times 10^{7}$ & $\begin{array}{l} \pm 0.5 \times 1 \\
0^{7}\end{array}$ & 25 & 29 \\
\hline \hline FC $^{\mathrm{e}}(\mathrm{MPN} / 100 \mathrm{ml})$ & $4.0 \times 10^{2}-1.1 \times 10^{8}$ & $1.08 \times 10^{7}$ & $\begin{array}{l} \pm 0.4 \times 1 \\
0^{7}\end{array}$ & 38 & 28 \\
\hline \hline SRB $^{\mathrm{f}}(\mathrm{MPN} / \mathrm{g}$ sludge $)$ & $3.6 \times 10^{3}-4.1 \times 10^{5}$ & $1.5 \times 10^{4}$ & $\begin{array}{l} \pm 0.5 \times 1 \\
0^{4}\end{array}$ & 33 & 11 \\
\hline \hline Sulphate (mg/l) & $1180-1300$ & 1250 & \pm 105 & 9 & 10 \\
\hline \hline Chloride (mg/l) & $8320-8500$ & 8400 & \pm 924 & 11 & 10 \\
\hline \hline
\end{tabular}

a S.D.=standard deviation.

b C.V.=coefficient of variation (\%).

c No.=number of samples.

d TC=total coliforms.

e $\mathrm{FC}=$ faecal coliforms.

f $\mathrm{SRB}=$ sulphate-reducing bacteria.

\section{Results and discussion}

\subsection{Effect of salts on the removal of faecal coliforms}

During a period of 590 days, the reactor was adapted to increasing influent salt concentrations of 5, 10 and $15 \mathrm{~g} / \mathrm{l}$. Fig. 1 shows that total coliform concentration reduction efficiency was higher than $95 \%$, with average values of $96.8 \%, 97.2 \%$ and $95.6 \%$, for 5,10 and $15 \mathrm{~g} / \mathrm{l}$ of salts concentration, respectively. The average values of total coliform concentration reduction efficiencies were very close each other and significant differences could not be established among them. 


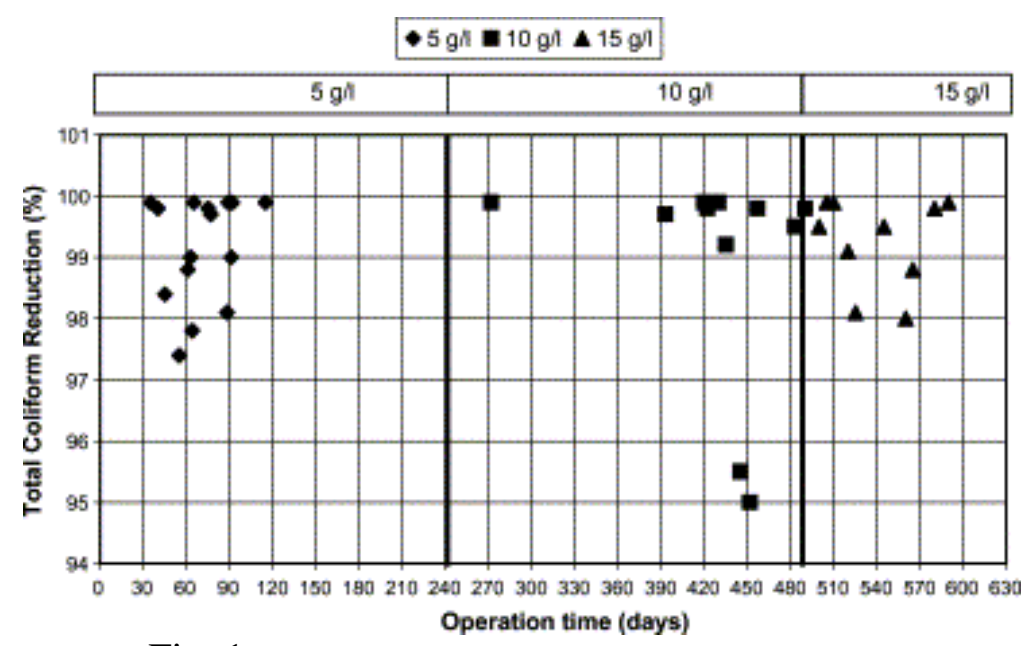

Fig. 1.

Variation of the reduction efficiency (\%) of total coliform concentration with the operation time during the addition of 5,10 and $15 \mathrm{~g} / \mathrm{l}$ of sea salts in the influent of the process.

\subsection{Removal of faecal coliforms after frequently feeding with new substrate}

The variation of the faecal coliform concentration with time at HRTs of 96 and $48 \mathrm{~h}$ is showed in Fig. 2. After four days of operation at a HRT of $96 \mathrm{~h}$, a significant reduction in the initial concentration of coliform from $2 \times 10^{7}$ to $2 \times 10^{2}$ cells $/ 100 \mathrm{ml}$ was observed, corresponding to 5 (base 10) logarithmic units. After the addition of the first new feed, a reduction of $3 \log _{10}$ units was produced in a period of six days. However, after adding the second feed with a concentration of faecal coliform of $10^{5}$ cells $/ 100 \mathrm{ml}$, the concentration in the effluent was reduced in $5 \log _{10}$ units in a period of seven days. At a HRT of $48 \mathrm{~h}$ the initial concentration of faecal coliform decreased by $5.5 \log _{10}$ units after two days of operation time. After each feed, the concentration of faecal coliform decreased again. These results indicate that after each feeding of wastewater to the reactor, a majority of coliforms were reduced in concentration, probably by adsorption to the biofilm associated to the support medium or to the colloidal solids in suspension in interstitial spaces.

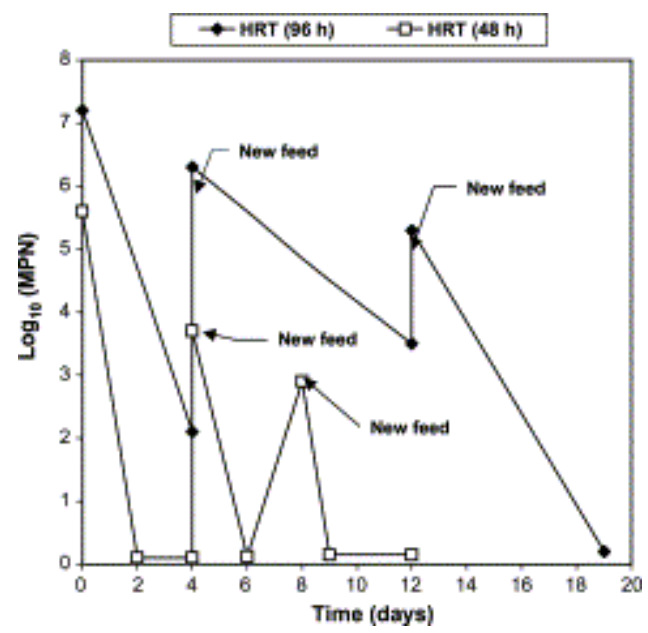

Fig. 2. 
Variation of the effluent faecal coliform concentration with the time for HRTs of 96 and $48 \mathrm{~h}$ at a sea salt concentration of $15 \mathrm{~g} / \mathrm{l}$.

The variability of the faecal coliform concentration with time at HRTs of 24 and $12 \mathrm{~h}$, respectively is shown in Fig. 3. As can be seen, when HRT was reduced to $24 \mathrm{~h}$, the initial population of faecal coliform in the effluent fell gradually from $6.4 \log _{10}$ units to 4.4 $\log _{10}$ units, resulting in a coliforms removal close to $3 \log _{10}$ units until the second day. It appears that a steady-state of the process is reached after three days and after that period the highest removal was achieved. When a new feed was added on the fourth day, the faecal coliform concentration decreased again, remaining constant up to day 7. This indicated that a maximum removal of $4 \log _{10}$ units was achieved in the anaerobic reactor operating at a HRT of $24 \mathrm{~h}$. At a HRT of $12 \mathrm{~h}$, until 1.5 days of operation, the concentration of faecal coliform in the effluent was not significantly reduced. However, this result was not observed when the reactor was fed with a fresh substrate containing an initial concentration of $4 \times 10^{3}$ cells $/ 100 \mathrm{ml}$ (3.6 $\log _{10}$ units). In this case, after 0.5 days, the faecal coliform population diminished until values lower than 3.0 cells $/ 100 \mathrm{ml}$, and remained at this concentration until the end of the experiment. The results obtained indicated an increase in the capacity of faecal coliform removal by the unit as the operation time and the HRT increased because of the increment of the sludge age or solids retention time (SRT). An increase of SRT is equivalent to an increase of microorganisms concentration in the reactor, which is thought to cause a better adaptability to the substrate. This fact contributes to increase the biofilm thickness and extension on the support. Therefore, the adsorption capacity of the biofilm and the microorganisms in suspension within interstitial spaces are also increased, contributing to increase the removal of faecal coliforms. Also, the removal efficiency was favored by the decrease in the hydraulic flow velocity of the fluid that was assumed to enhance adsorption and sedimentation mechanisms.

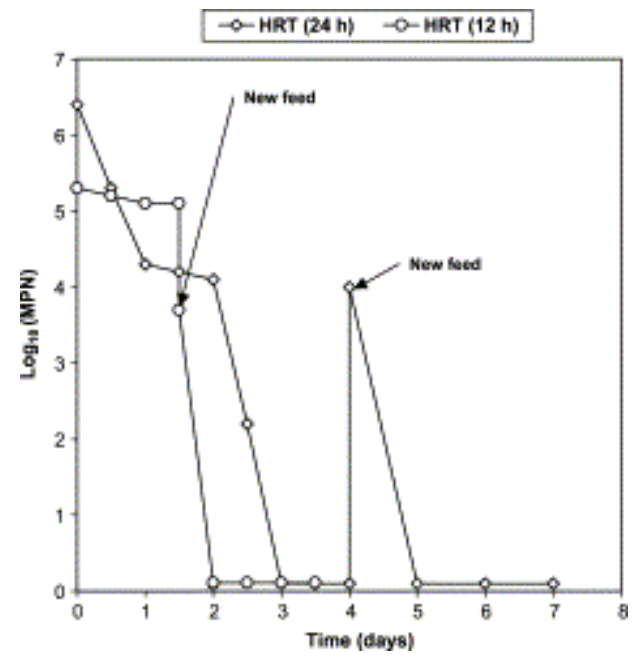

Fig. 3.

Variation of the effluent faecal coliform concentration with the time for HRTs of 24 and $12 \mathrm{~h}$ at a sea salt concentration of $15 \mathrm{~g} / \mathrm{l}$.

\subsection{Effect of HRT on the removal efficiency of total and faecal coliforms}

The effect of HRT on the removal of total and faecal coliform when adding $15 \mathrm{~g} / \mathrm{l}$ of sea salts is shown in Fig. 4. HRTs in the range from 96 to $24 \mathrm{~h}$, generated total and faecal 
coliform removals higher than 99\%. However, at a HRT of $12 \mathrm{~h}$, the removal efficiency dropped to $90-92 \%$, perhaps as a consequence of bacterial washout from the reactor because of a sudden increase in hydraulic flow velocity of the fluid. According to the results of the variance analysis for a probability level of $95 \%(p \leqslant 0.05)$, there were no significant differences in average values of faecal coliform removal for HRTs in the range of 24-96 h, while at a HRT of $12 \mathrm{~h}$, the removal efficiency was significantly lower $(p \leqslant 0.05)$.

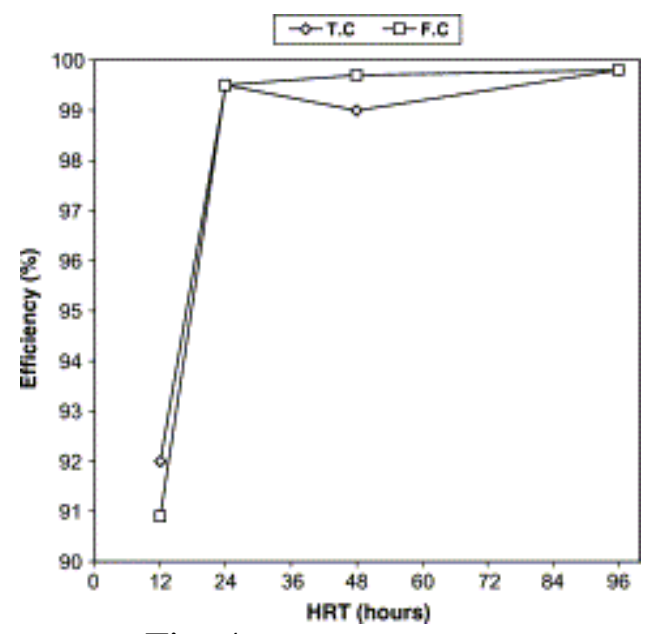

Fig. 4.

Effect of the HRT on the reduction efficiency of total and faecal coliform concentration at a sea salt concentration of $15 \mathrm{~g} / \mathrm{l}$.

\subsection{Concentration reduction of faecal coliforms in different zones of the support medium}

Faecal coliforms were isolated and enumerated at the end of the experiments from the microorganisms attached to the support medium (biofilm), at the upper $(1.30 \mathrm{~cm}$ height), medium (65 cm height) and bottom zones of the reactor. The concentrations and the removal efficiencies of faecal coliform at different heights of the support medium are shown in Fig. 5. As can be seen, a higher percentage of faecal coliform was retained in the upper part of the support, which may be correlated with a higher solids retention in a down-flow anaerobic filter (Johnson et al., 1994). It was found that $94.9 \%$ of faecal coliforms were retained in the upper zone, $5.0 \%$ were retained in the intermediate zone and only $0.01 \%$ were retained in the lower zone. These values corresponded to concentrations of $3 \times 10^{4}, 1.6 \times 10^{3}$ and 3 cells $/ 100 \mathrm{~g}$ of biofilm, in the upper, medium and lower zones of the reactor, respectively. The comparison of the bacteria recovered from the biofilm with the average removal in the process for HRTs of 96, 48 and 24 h suggested that a major part of bacteria were retained by colloidal suspended solids present in the interstitial spaces or on the surface of the biofilm as a consequence of solids accumulation that escaped from the reactor during dismantling. This speculation may be corroborated by the presence of salts mixed with organic matter in suspension that were observed in the effluent when the HRT was decreased, probably caused by the accumulation of relatively insoluble salts (mainly $\mathrm{CaCl}$ ) present in the influent. 


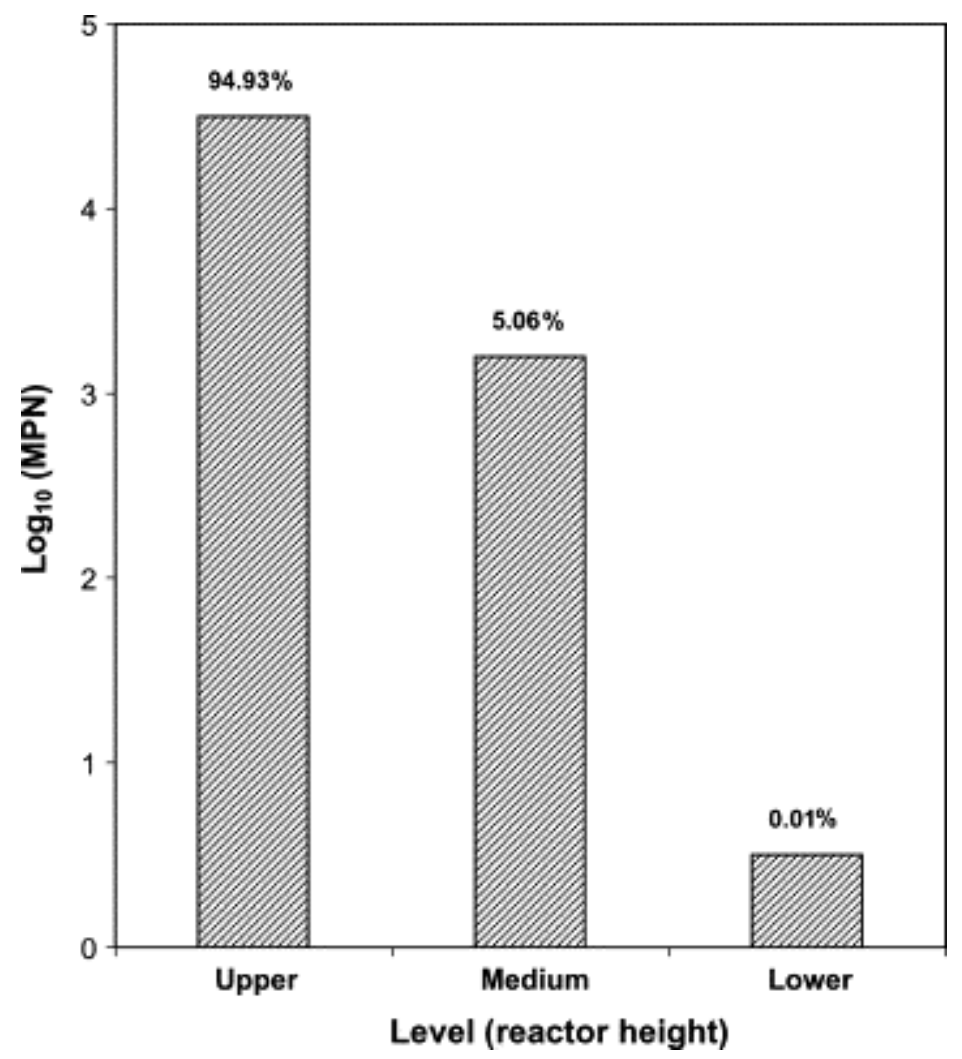

Fig. 5.

Concentrations and reduction efficiencies of faecal coliforms at the different levels of the support medium. Percentages were computed from the overall faecal coliform retained in the support.

\subsection{Effect of HRT on organic matter and nutrient removal}

The variability of the removal efficiency of total COD, organic nitrogen and phosphorous with HRT is shown in Fig. 6. The removal efficiency of total COD was higher than $90 \%$ for a HRT of $96 \mathrm{~h}$ and remained over $68 \%$ at a HRT of $12 \mathrm{~h}$. Removal efficiencies of organic-N and total-P were higher than $70 \%$ and $40 \%$, respectively, at an HRT of 96 h, and higher than 38\% and 25\%, respectively, at a HRT of $12 \mathrm{~h}$. The form of the curves generated was very similar to those obtained for faecal and total coliform concentration reduction. Total COD removal efficiency decreased in 3\% when the HRT decreased from 96 to $48 \mathrm{~h}$, while total-P removal efficiency remained constant. When the HRT decreased from 48 to $24 \mathrm{~h}$, the total COD removal efficiencies decreased significantly while total-P removal efficiency only decreased in $1 \%$. However, sudden reductions were observed when the HRT diminished from 24 to $12 \mathrm{~h}$ for both total COD and phosphorous. Analysis of variance (ANOVA) showed no significant differences at HRTs higher than $24 \mathrm{~h}$ with $p \leqslant 0.05$. In the case of organic-N, the removal efficiency increased in 10\% when the HRT increased from 12 to $24 \mathrm{~h}$. These results suggest a great influence of the HRT on the process performance as was previously observed for coliform bacteria concentration reduction. The reduction of the HRT may have affected the development of methanogenic bacteria that could be already stressed by the accumulated salts. The values of biogas production and methane gas concentrations at different HRTs had a great dispersion and standard deviations of these parameters were very high. Table 3 shows the experimental results obtained. In spite of the dispersion of 
the data, the average values show that an increase of HRT caused a decrease of biogas and methane production. However, the average specific methane yield (SMY) increased as the HRT increased. An increase in SMY of 64\% was observed when HRT increased from 12 to $24 \mathrm{~h}$, while the increase was of $43 \%$ when HRT increased from 24 to $96 \mathrm{~h}$. These results underline the fact that methane production may be affected at a HRT of 12 $\mathrm{h}$ and at HRTs higher than $24 \mathrm{~h}$, the process was capable of overcoming the inhibitory effect of salinity. At a HRT of $24 \mathrm{~h}$ optimum results were obtained while at a HRT of 12 $\mathrm{h}$, a considerable decrease in removal efficiencies was demonstrated.

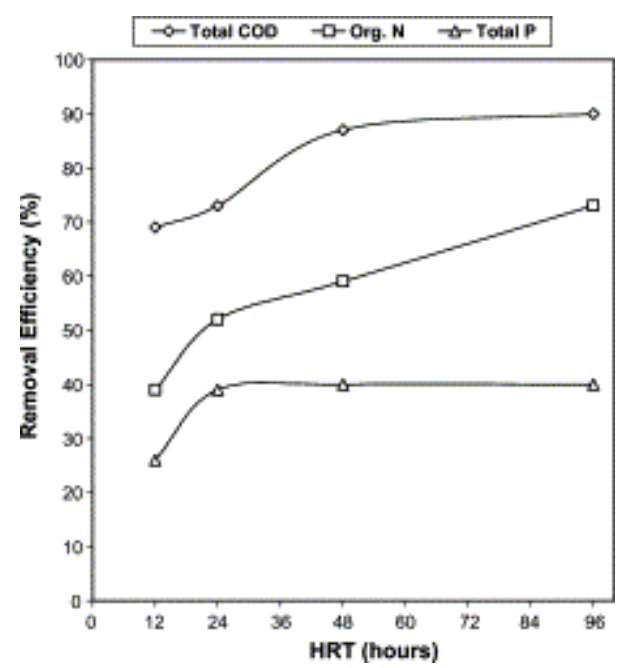

Fig. 6.

Variation of the removal efficiencies of total COD, organic-N and total-P with the HRT.

Table 3.

Effect of HRT on biogas and methane production for a total salt concentration of $15 \mathrm{~g} / \mathrm{l}$

\begin{tabular}{|c|c|c|c|c|c|}
\hline $\begin{array}{l}\text { HRT } \\
\text { (h) }\end{array}$ & $\begin{array}{l}\text { Biogas } \\
\text { production }^{a}(\mathbf{l} / d)\end{array}$ & $\begin{array}{l}\text { S.D. } \\
(\mathbf{l} / \mathbf{d})\end{array}$ & $\begin{array}{l}\text { Methane } \\
\text { production }^{\mathrm{a}}(\mathbf{l} / \mathrm{d})\end{array}$ & $\begin{array}{l}\text { S.D. } \\
\text { (l/d) }\end{array}$ & $\begin{array}{l}\mathrm{SMY}^{\mathrm{c}} \quad(\mathrm{l} \\
\left.\mathrm{CH}_{4} / \mathrm{g} \mathrm{COD}\right)\end{array}$ \\
\hline 12 & 0.65 & \pm 0.46 & 0.30 & \pm 0.24 & 0.14 \\
\hline 24 & 0.36 & \pm 0.29 & 0.25 & \pm 0.21 & 0.23 \\
\hline 48 & 0.19 & \pm 0.16 & 0.14 & \pm 0.12 & 0.26 \\
\hline 96 & 0.12 & \pm 0.10 & 0.09 & \pm 0.08 & 0.33 \\
\hline
\end{tabular}

a

Average values.

b

S.D.=standard deviation.

C

SMY=average specific methane yield ( $\mathrm{l} \mathrm{CH}_{4} / \mathrm{g} \mathrm{COD}$ added). 


\subsection{Anaerobic toxicity of chlorides, sulphates and sodium}

The different loads of $\mathrm{Na}^{+}, \mathrm{Cl}^{-}$and $\mathrm{SO}_{4}{ }^{2-}$ ions applied to the reactor as a function of the HRT are shown in Fig. 7. At a HRT of $12 \mathrm{~h}$, the loads of $\mathrm{Na}^{+}, \mathrm{Cl}^{-}$and $\mathrm{SO}_{4}{ }^{2-}$ applied were 8, 15 and $3 \mathrm{~g} / \mathrm{l}$ day, respectively, values that could be toxic for microorganisms (McCarty and McKinney, 1961). Chlorides, specially $\mathrm{NaCl}$, accumulated within the reactor forming lumps with solids resulted in a progressive increase of chloride concentration with the consequential risk of bacteria plasmolysis. A sodium concentration of $4.6 \mathrm{~g} / \mathrm{l}$ at the influent (higher than that reported by McCarty and McKinney, 1961, as inhibitory for anaerobic digestion processes) indicated that the reactor operated under critical conditions.

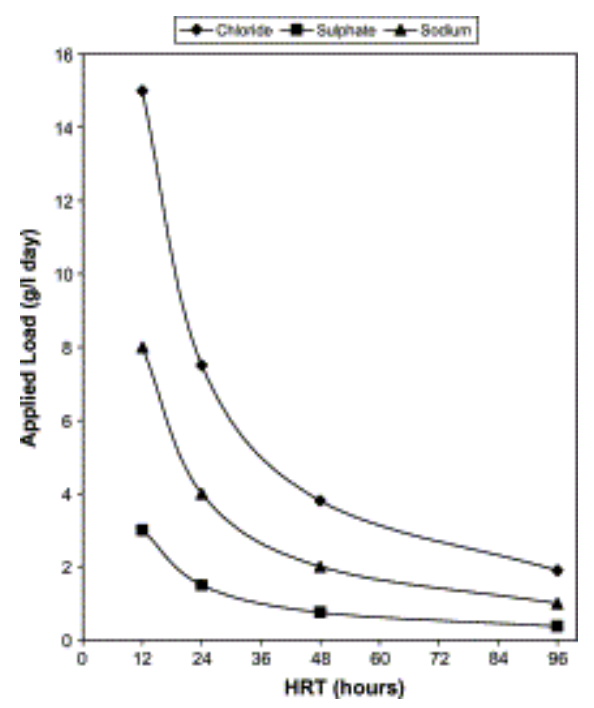

Fig. 7.

Loadings of chlorides, sulphates and sodium added to the reactor for each HRT applied.

Sulphate removal was close to 50\%, similar to the values reported by Saw et al. (1986), when treating edible oil wastes, and very close to values obtained by Rintala et al. (1991). The toxicity of sulphates could be minimized with a major activity of sulphatereducing bacteria, since they could theoretically be able to remove most of the organic matter and nutrients present in the influent.

Lens et al. (1998) reported that a high COD reduction efficiency could be achieved via sulphate reduction when the $\mathrm{COD} /$ sulphate ratio was close to 0.67 , but for $\mathrm{COD} /$ sulphate ratios higher than 0.67 , this behaviour could be possible if methanogenesis also occurs. The variability of total COD removal efficiency with time and COD/sulphate ratios at different HRTs is shown in Fig. 8. The COD/sulphate ratio was maintained in the range of between 0.6 and 2.0, and the methanogenic and sulphate-reducing bacteria, probably competed for the available substrates at $\mathrm{COD} /$ sulphate ratios of between 1.7 and 2.0, whereas sulphate-reducing bacteria can become the predominant organisms at COD/sulphate ratios of between 0.6 and 1.7, as previously described by Choi and Rim (1991). Although the $\mathrm{H}_{2} \mathrm{~S}$ production could be enhanced as decreased the HRT and the competition of methanogenic bacteria with sulphate-reducing bacteria (SRB), its concentration in the liquid phase was not expected 
to reach a toxic level (5\%) because $\mathrm{pH}$ values were increased in the range of 7.2-8.4, prevailing the alkaline conditions.

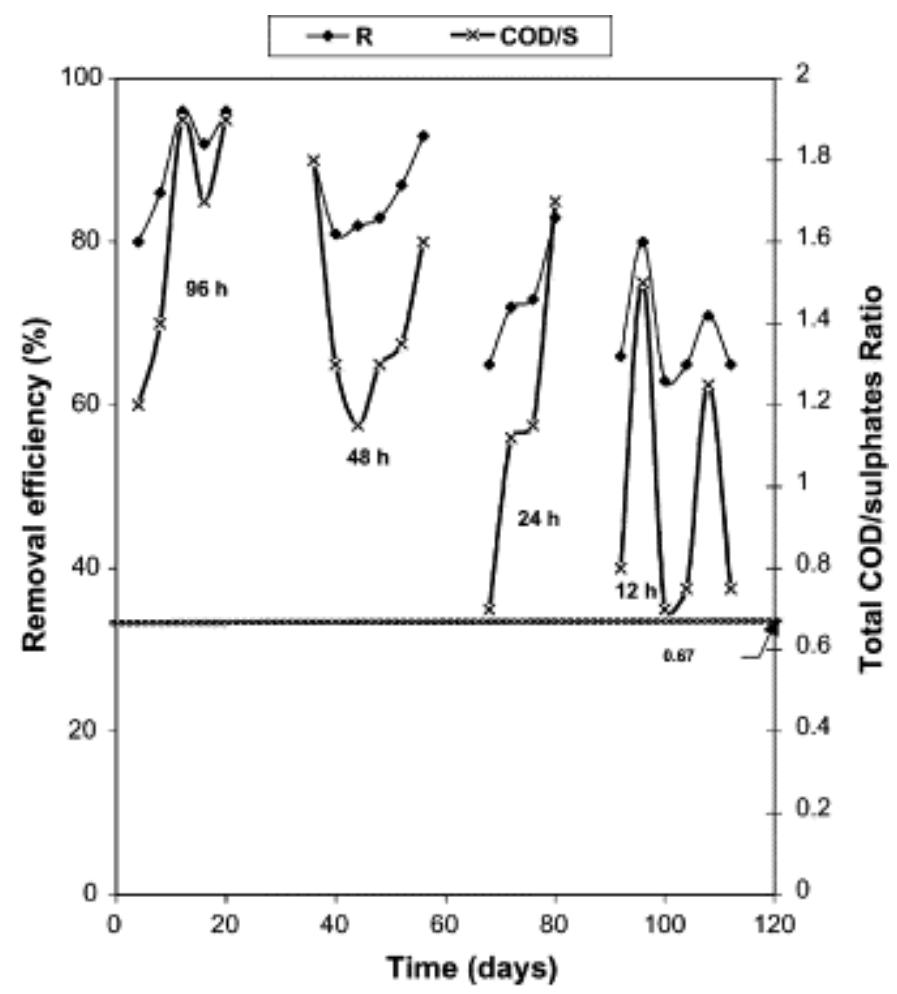

Fig. 8.

Variation of the total COD removal efficiency with the operation time and COD/sulphate ratio at different HRTs.

Fig. 8 illustrates that an increase of the TCOD/sulphates ratio determined an enhancement of process performance. A COD/sulphate ratio between 0.6 and 1.5 may cause an inhibition of methanogenic bacteria (as was previously described), reducing the adsorption capacity of the biofilm and increasing the washout probabilities, which caused the sudden deterioration of the process performance.

The isolation and enumeration of sulphate-reducing bacteria in the digested sludge obtained at the end of the experiments corresponding at a HRT of $12 \mathrm{~h}$ yielded values of sulphate-reducing bacteria (SRB) in a range of 5.0-9.0 $\times 10^{3}$ cells/g sludge with an average of $7.6 \times 10^{3}$ cells/g sludge, while at $48 \mathrm{~h}$ a concentration in the range of $1.2 \times 10^{2}-2 \times 10^{3}$ cells/g sludge with an average of $9.0 \times 10^{2}$ cells/g sludge was obtained. The diminution of sulphate-reducing bacteria concentration in the digested sludge compared to that observed in the raw waste sludge may have been due to the progression of the methanogenic conditions, which were unfavourable for SRB development. The increase of the HRT also contributed to enhance the methanogenic conditions and to reduce the concentration of SRB.

According to Lens et al. (1998), the experimental results obtained from their study demonstrated that bacteria were partially inhibited when concentrations of $\mathrm{Na}^{+}$ exceeded $11 \mathrm{~g} / \mathrm{l}$, occurring a 50\% of inhibition for concentrations higher than $15 \mathrm{~g} / \mathrm{l}$. Therefore, a slight inhibition could have occurred at $\mathrm{Na}^{+}$concentrations of $4.6 \mathrm{~g} / \mathrm{l}$ in this study, due to the relatively high COD and nutrient removal efficiencies achieved during 
this study. The results obtained in this case, suggested that concentrations of $\mathrm{Cl}^{-}=8.4$ $\mathrm{g} / \mathrm{l}, \mathrm{SO}_{4}{ }^{2-}=1.25 \mathrm{~g} / \mathrm{l}$ and $\mathrm{Na}^{+}=4.6 \mathrm{~g} / \mathrm{l}$ did not affect the process performance.

\section{Acknowledgments}

The authors wish to express their gratitude to the Spanish "Ministerio de Educación, Cultura y Deportes", the "Program of Scientific Cooperation with Iberoamérica (Spanish Foreign Ministry)" and "Consejería de Educación y Ciencia" of the "Junta de Andalucía" for the financial support and to the "Ministerio de Ciencia, Tecnología y Medio Ambiente” of Cuba and “Alexander von Humboldt Foundation” of Germany.

\section{References}

APHA (American Public Health Association), AWWA, WPCF, 1989. Standard Methods for the Examination of Water and Wastewater, 17th ed. APHA, Washington, DC, USA.

T.D. Brock

Biology of Microorganisms

Prentice-Hall, Englewood Cliffs, NJ, USA (1970)

L. Chabalina

Inform about the Physical-Chemical Characterization of Sewage in the Tourist Facility "Marina Hemingway" in Havana City

Center for the Environmental Management of Bays CIMAB, Cuba (1996) 4 pp (in Spanish)

E. Choi, J.M. Rim

Competition and inhibition of sulfate reducers and methane producers in anaerobic treatment

Water Science \& Technology, 23 (1991), pp. 1259-1264

D.R. Cullimore, T. Viraraghavan

Microbiological aspects of anaerobic filter treatment of septic tank effluent at low temperatures

Environmental Technology, 15 (1994), pp. 165-173

L.A. De Baere, M. Devocht, P.V. Assche, W. Verstraete

Influence of high $\mathrm{NaCl}$ and $\mathrm{NH}_{4} \mathrm{Cl}$ salt levels on methanogenic associations

Water Research, 18 (1984), pp. 543-548

E.A. Duarte, B. Mendez, J.S. Oliveira

Removal of salmonella, streptococci and coliforms in pig breeding effluent by anaerobic mesophilic digestion

Water Science \& Technology, 26 (1992), pp. 2126-2172 
Feijoo, G., 1991. Sodium Toxicity in Anaerobic Digestion Processes: Phenomena of Antagonism and Adaptation. MSc Dissertation, University of Santiago de Compostela, Spain

García, A.M., 1977. Tecnología de la sal marina. Ministerio de Minería y Geología, Habana city, Cuba

M. Henze, P. Harremoes

Anaerobic treatment of wastewater in fixed film reactors. A literature review

Water Science \& Technology, 15 (1983), pp. 1-101

K.A. Johnson, A.D. Wheatley, O. Monroy

Mixing and solids accumulation in anaerobic filters. Two case studies

Environmental Technology, 15 (1994), pp. 263-270

F. Kargi, A.R. Dincer

Biological treatment of saline wastewater by fed-batch operation

Journal of Chemical Technology Biotechnology, 69 (1997), pp. 167-172

F. Kargi, A. Uygur

Effect of liquid phase aeration on performance of rotating biodisc contactor treating saline wastewater

Environmental Technology, 18 (1997), pp. 623-630

F. Kargi, A. Uygur

Biological treatment of saline wastewater in a rotating biodisc contactor by using holophilic organisms

Bioprocess Engineering, 17 (1997), pp. 81-85

I.J. Kugelman, P.L. McCarty

Cation toxicity and stimulation in anaerobic waste treatment

Journal WPCF, 37 (1965), pp. 97-116

P.N. Lens, A. Visser, A.J.H. Janssen, P.L. Hulshoff, G. Lettinga

Biotechnological treatment of sulfate-rich wastewaters

Critical Reviews in Environmental Science \& Technology, 28 (1) (1998), pp. 41-88

A. Li, G. Gouwei

The treatment of saline wastewater using a two-stage contact oxidation method

Water Science \& Technology, 28 (1993), pp. 31-33

McCarty and McKinney, 1961

P.L. McCarty, R.E. McKinney

Salt toxicity in anaerobic digestion

Journal WPCF, 33 (4) (1961), pp. 399-415 
S. Morris, K. Yehuda

Efficiency of rotating biological contactor in removing pathogenic bacteria from domestic sewage

Water Research, 24 (1990), pp. 1125-1128

F.S. Ogbondeminu, F.C. Okoye

Microbiological evaluation of an untreated domestic wastewater. Aquaculture system

Journal of Aquaculture Tropical, 7 (1992), pp. 27-34

F. Omil, R.J. Mendez, J.M. Lema

Characterization of biomass from a pilot plant digester treating saline wastewater

Journal of Chemical Technology Biotechnology, 63 (4) (1995), pp. 384-392

G.F. Parkin, M.A. Sneve, H. Loos

Anaerobic filter treatment of sulphate containing wastewater

Water Science \& Technology, 23 (1991), pp. 1283-1291

Parr, J., Smith, M.D., Stear, R.M., 1997. Decreasing freshwater demand: dual supply systems. In: Proceedings of the 23rd WEDC Conference at Durban, South Africa, September

O. Reyes, E. Sánchez, N. Rovirosa, R. Borja, M. Cruz, M.F. Colmenarejo, R. Escobedo, M. Ruiz, X. Rodríguez, O. Correa

Low strength wastewater treatment by a multistage anaerobic filter packed with waste tyre rubber

Bioresource Technology, 70 (1999), pp. 55-60

J. Rintala, J.L. Sanz-Martin, G. Lettinga

Thermophilic anaerobic treatment of sulphate rich pulp and paper integrate process water

Water Science \& Technology, 24 (1991), pp. 149-160

Sánchez, E., Reyes, O., Cruz, M., Borja, R., Romero, A., 1995. Organic material and pathogens removal using an immobilization reactor. In: Proceedings of the International Conference Advances in Modern Biotechnology "Biotecnología Habana '95", Book of Short Reports, vol. 3, pp. 1 (in Spanish)

E. Sánchez, R. Borja, O. Reyes, M. Cruz, M.F. Colmenarejo

Treatment of sewage wastewater from tourist areas by anaerobic fixed-bed reactor World Journal of Microbiology \& Biotechnology, 13 (1997), pp. 315-318

Saw, C.B., Anderson, G.K., Sanderson, J.A., 1986. Comparison of the anaerobic contact and packed bed processes for the treatment of edible oil wastes. In: Proceedings of the 41st Industrial Wastes Conference at Purdue University, West Lafayette, IN, pp. 178187 
Smith, M.D., Stear, R.M., Parr, J., 1996. Seawater for non-potable uses. In: Proceedings of the 22nd WEDC Conference; Reaching the Unreached: Challenges for the 21st Century at New Delhi, India, pp. 3

G. Tchobanoglous, F.L. Burton

Wastewater Engineering: Treatment, Disposal and Reuse

(third ed.)Metcalf \& Eddy, New York, USA (1991)

M.C. Veiga, R. Méndez, J.M. Lema

Wastewater treatment for fisheries operations

A.M. Martin (Ed.), Fisheries Processing Biotechnological Application, Chapman and Hall, London (1994), pp. 344-369

WHO (World Health Organization), 1996. Guidelines for Drinking Water Quality. Vol. 2: Health Criteria and Other Supporting Information. Part 1. Microbiological Aspects, 2nd ed. Geneva, Italy, pp. 7-117 